\title{
IAMJ
}

INTERNATIONAL

AYURVEDIC

MEDICAL JOURNAL

Research Article

ISSN: 23205091

Impact Factor: 5.344

\section{PHARMACEUTICO- ANALYTICAL STUDY OF BANDANAARU (BRIDELIA SCANDENS R.) GRANULES - A MODIFIED ETHNO-MEDICINE}

\author{
Anusha R ${ }^{1}$, Soumya Saraswathi², Subrahmanya Padyana ${ }^{3}$ \\ ${ }^{1}$ IV Year BAMS, Alva's Ayurveda Medical College, Moodubidire, Karnataka, India \\ ${ }^{2}$ Assosciate Professor, Dept. of Ayurveda Samhita and Siddhanta, Alva's Ayurveda Medical College Moodubidire, \\ Karnataka, India \\ ${ }^{3}$ Director, Alvas Traditional Medicine Archive (ATMA) and Research Centre, Moodubidire, Karnataka, India
}

Email: anushabujji1999@gmail.com

https://doi.org/10.46607/iamjp04042020

(Published online: May 2020)

Open Access

(C) International Ayurvedic Medical Journal, India 2020

Article Received: 09/05/2020 - Peer Reviewed:10/05/2020 - Accepted for Publication: 10/05/2020

Check for updates

\section{ABSTRACT}

Folklore medicines broadly mean all aspects of direct relationship of man with plants. It expands its scope into the use of plants as medicine, food, fibres, dyes, tans, taboos, avoidances, and even magico religious beliefs. Ayurveda is known for the use of poly-herbal formulations and multi-component therapeutics for the management of health and diseases. The overall aim of the drug standardization is to ensure the quality, efficacy and the uniformity of the products in terms of their chemical and biological properties. Bandanaaru [Bridelia scendens (Roxb) Willd.] is one of the mostly practised folklore drugs for its nutritional value. It is believed to be equivalent to breast milk to the kids. Along with this drug, the drugs like Bala and Shritala are also added and nutritional granule is prepared based on Standard operative procedure [SOP] of granules mentioned in API. This article reports on standardisation of Bandanaaru granules a polyherbal product used as a nutritive supplement. The prepared granule has shown pleasant sweet taste with good palatability. Preliminary qualitative phytochemical studies have shown the presence of Carbohydrates, Proteins, Starch, Flavonoids, Steroids, Vitamins etc.

Keywords: Folklore, Bandanaaru (Bridelia scandens), Bala, Shritala, SOP 


\section{INTRODUCTION}

Ayurveda is the science of life with the aim of maintaining health and curing diseases. Diet plays a key role in maintaining health ${ }^{1,2}$. Ayurveda emphasizes that a diet should contain proper amount of nutrients which is lacking now in present era. Malnutrition has become urgent global health issue with under nutrition killing or disabling million of children every year. Malnutrition also prevents million more reaching their full intellectual and productive potential ${ }^{3}$. It makes the child more susceptible to infection, recovery is slower, and mortality is higher. Undernourished children do not grow to their full potential of physical and mental abilities. Malnutrition in infancy and childhood leads to stunted growth. It also manifests by clinical signs of malnutrition and vitamin deficiencies ${ }^{4}$. In India about $2 / 3$ portion of the children are under the age of 5 years are malnourished, among the 5-8\% are severely malnourished. About $75 \%$ of population resides in the village; of the total rural population around $50 \%$ is still under the poverty lines. Majority of children in India are not in a position to get adequate nourishment because of very low capita income of their families ${ }^{5}$. A significant proportion of these children live in economic and social environment which impedes the child's physical and mental development, this condition include poverty, poor environment sanitation, diseases, infection, inadequate access to primary health care, inappropriate childcaring and feeding practices ${ }^{5}$.
The plant Bridelia scandens (Roxb) Wild. belongs to the family Euphorbiaceae, known as Bandanaaru in Kannada, widely available in Western Ghats which is practised as a folklore drug for its nutritive value and believed to be equivalent to breast milk $\mathrm{k}^{6}$. The drug has been proved for its safety and efficacy by experimental study $^{7}$. The plants such as Bala (Sida cordifolia L.) and Shritala (Caryota urens L.) are also commonly used in case of general debility as nutritive herb by the folklore people of Karnataka. The decoction of the leaves and barks of Bridelia scandens (Roxb) Willd. and roots of Sida cordifolia L. are used as general tonic, where as the pith of Caryota urens L. known as Eendu powder in Kannada is believed to be highly nutritive by the village people of coastal Karnataka ${ }^{6}$.

Hence, the present study is undertaken to evaluate the standard operative procedure and analytical study of herbal nutritive granules by using the above herbal drugs which is a modified ethno-medicine.

\section{Materials and Methods}

Preparation of Herbal Nutritive Granules: The raw drugs are collected from the natural habitat and also from the local market of Dakshina Kannada District and authenticated by the expert botanist. The ingredients used for the preparation of herbal nutritive granules are as mentioned in the table number 1 .

Table 1

\begin{tabular}{|c|l|l|l|l|}
\hline Sl. No. & Name Of The Drug & Latin Name & Part Used & Quantity \\
\hline 1. & Bandanaaru & Bridelia scandens & Bark And Leaves & $1 \mathrm{~kg}$ \\
\hline 2. & Bala & Sida cordifolia & Root & $1 \mathrm{~kg}$ \\
\hline 3. & Shritala & Caryota urens & Pith & $1 \mathrm{~kg}$ \\
\hline 4. & Kajutaka & Anacardium occidentale & Seed Kernel & $100 \mathrm{~g}$ \\
\hline 5. & Ela & Elatteria cardamomum & Seeds & $50 \mathrm{~g}$ \\
\hline 6. & Jala & - & - & $161 \mathrm{tr}$ \\
\hline 7. & Sharkara & - & - & $4 \mathrm{~kg}$ \\
\hline
\end{tabular}

Preparation of herbal granules was carried out at Bhaishajya Kalpana Lab., Alva's Ayurveda Medical College, Moodubidire. General method of preparation emphasized for Khanda Paka is followed in the preparation of Granules ${ }^{8}$. Dried raw materials such as leaves and barks of Bridelia scandens and roots of Sida cordifolia were taken in equal proportions were crushed to prepare coarse powder separately and mixed 
with 8 parts of water in a stainless-steel container. Continuous mild heat was applied until it was reduced to one- fourth of its initial quantity. During heating process, continuous stirring was done to facilitate the evaporation and avoid any deterioration due to burning of materials. After a desirable reduction in volume was achieved, it was filtered. To the 4ltr of decoction, $2 \mathrm{~kg}$ of sugar was added and continued to heat. When it attains 2 thread consistencies, powders of Shritala, Kajutaka and Ela were added and stirred well until it attains granular form. Granules obtained were stored in the airtight container.

\section{Pharmaceutico-Analytical Study}

Pharmaceutico-analytical study was carried to establish the basic standards for Bandanaaru granules. The studies were conducted in the Department of Dravya Guna, Department of Bhaishajya Kalpana of Alva's Ayurveda Medical College, Moodubidire and Department of Biotechnology, Alva's College, Moodubidire as per API Standards 8 .
To find the Rasa and palatability of the nutritive granule, Nipata method ${ }^{9}$ was followed. The study was conducted in 30 volunteers who were intelligent to identify the taste and express it. The volunteers were the Ayurveda students and are in the age group of 18-23 years. Volunteers were requested to taste the prepared granules after washing their month with distilled water. They were requested to write down the taste they felt instantaneously, and the taste felt after half a minute on a slip of paper. The results were interpreted based on the Rasa perceived. The taste perceived in first half minute is considered as the Pradhana Rasa and that perceived after as Anurasa. The volunteers were also asked to write about palatability, smell etc.

\section{Observations and Results}

\section{Total obtained quantity of Herbal Nutritive} Granules $=4.850 \mathrm{~kg}$

2. Organoleptic Study: The opinion of the volunteers regarding organoleptic character of the Bandanaaru Granules were documented as mentioned in the table no. 2

Table 2

\begin{tabular}{|l|l|l|}
\hline Colour & Light Brown & $100 \%$ \\
\hline Appearance & Granule & $100 \%$ \\
\hline Smell & Pleasant/aromatic & $100 \%$ \\
& Unpleasant & $0 \%$ \\
\hline \multirow{2}{*}{ Taste } & Sweet & $72 \%$ \\
& Sweet with tinge of astringent taste & $28 \%$ \\
\hline Palatability & Non palatable & $0 \%$ \\
& Palatable with difficulty & $0 \%$ \\
& Palatable & $100 \%$ \\
\hline Others & Feeling of nausea & $0 \%$ \\
\hline
\end{tabular}

3. Analytical Study: The results of analytical studies conducted for the Bandanaaru granules as mentioned in the table no. 3

\section{Table 3}

\begin{tabular}{|l|l|l|}
\hline Sl. No. & Analytical Study & Results \\
\hline $\mathbf{1 .}$ & Bulk density & $0.58 \mathrm{~g} / \mathrm{cc}$ \\
\hline 2. & Tap density & $0.70 \mathrm{~g} / \mathrm{cc}$ \\
\hline 3. & Compressibility & $18.5 \%$ \\
\hline 4. & Flow property & 25 \\
\hline
\end{tabular}


3. Determination of $\mathbf{p H}$ Value $\mathrm{pH}$ value of the Granule 7.80

4. Qualitative analysis: Qualitative analysis of the phytochemical in the granules as shown in the table number 4

Table 4

\begin{tabular}{|l|l|l|}
\hline Sl. No. & Organic Component & Qualitative analysis \\
\hline 1. & Carbohydrates & Present \\
\hline 2. & Proteins & Present \\
\hline 3. & Starch & Present \\
\hline 4. & Alkaloids & Present \\
\hline 5. & Flavanoids & Present \\
\hline 6. & Triterpenoids & Present \\
\hline 7. & Phenolics & Present \\
\hline 8. & Tannins & Present \\
\hline 9. & Saponin & Absent \\
\hline 10. & Steroids & Present \\
\hline 11. & Resins & Absent \\
\hline 12. & Vitamins & Present \\
\hline
\end{tabular}

\section{DISCUSSION}

Bandanaaru (Bridelia scandens (Roxb) Willd.) has been used widely by the folklore practitioners of Dakshina Kannada District owing to its multiple uses in different ailments. The decoction of the bark is useful in case of anemia, general debility and fever ${ }^{6}$. It is believed to be equivalent to breast milk to the kids ${ }^{6}$. Decoction of the leaf is also beneficial in anemia during pregnancy ${ }^{6}$. The plant is having potent antioxidant property and immunological effect ${ }^{10}$. Hence an attempt is made to bring new formulation into stream of science to aid in health benefits of Bandanaaru along with Bala and Shritaala, and to study SOP (Standard Operative Procedure) of the pharmaceutical preparation of granules. Palatability test conducted among 30 volunteers proved that the granules have more palatability, less irritability and good aroma. The analytical studies undertaken showed the results of bulk density, tap density, compressibility, flow property which were observed to be within the limits of permissible values as per Ayurvedic Formulary of India ${ }^{11}$. Carbohydrates, Proteins, Starch, Phenolics, Flavonoids, Steroids, Vitamins etc are having their own nutritive value in the rejuvenation of all the age group of the mankind.

\section{CONCLUSION}

The prepared granule has shown pleasant sweet taste with good palatability. Preliminary qualitative phytochemical studies have shown the presence of Carbohydrates, Proteins, Starch, Phenolics, Flavonoids, Steroids, Vitamins etc. The analytical studies have shown the results of bulk density, tap density, compressibility, flow property which were observed within the limits of permissible values. Further, these granules can be utilized for clinical trial and can be recommended for wider therapeutic as well as nutritional use in future.

\section{REFERENCES}

1. Agnivesha, Charaka Samhita, with Ayurveda Deepika commentary of Chakrapanidatta, edited by Vaidya Yadavjitrikamji acharya published by Chowkambaorientalia, Varanasi, reprint 2011, Sutra Sthana, Chapter 30, shloka 26, page no 187

2. Indradeva Tripathi, Raja Nighantu of Narahari Pandith, Chaukhamba Krishnadas Academy, Varanasi, 2006.

3. Principles of parenting: meeting children's needs 1995. Available at: http:// www.aces.edu/pubs/docs/h/he0685/

4. K.Park, Park's textbook of Preventive and social medicine $23^{\text {rd }}$ edition published by $\mathrm{M} / \mathrm{s}$ Banarsidas Banot 1167, Premnagar Jabalpur,pg 550. 
5. H. Darlenemarin. Extension nutrition specialist north east research. Available from http:/ www.nnncc.org/ /nutrition.pres.html. april1997

6. Subrahmanya Padyana et al. Ethno-medico-botany of Moodabidri range in Child Health Care Int. Res. J. Pharm. 2018, 9 (12)

7. Kiran S Vasist, Bridelia scandens: Review on traditional uses and pharmacological aspects, Int. J. of Research in Eng. And Tech. 2016,9.

8. Anonymous, The Ayurvedic Pharmacopoeia of India, Part I, Vol. V, Government of India, Ministry of AYUSH, New Delhi, 2016.

9. Dr. S C Dhyani, Rasa panchaka, Chowkamba Krishnadas Academy, Oriental publisher and distributors.

10. Preetham. J etal., Bridelia scandens: Review on traditional uses and pharmacological aspects: IJRET, January 2017

11. Anonymous, The Ayurvedic Formulary of India, Part I, Vol. I, Government of India, Ministry of AYUSH, New Delhi, 2006.

\section{Source of Support: Nil}

\section{Conflict of Interest: None Declared}

How to cite this URL: Anusha $\mathrm{R}$ et al: PharmaceuticoAnalytical Study Of Bandanaaru (Bridelia Scandens R.) Granules - A Modified Ethno-Medicine. International Ayurvedic Medical Journal \{online\} 2020 \{cited May, 2020\} Available from: http://www.iamj.in/posts/images/upload/2335 2339.pdf 